\title{
Dramat. Twórczość. Transgresja. Przestrzenie intersubiektywnych doświadczeń w mistrzowskim dyskursie
}

\begin{abstract}
Halina Monika Wróblewska, Dramat. Twórczość. Transgresja. Przestrzenie intersubiektywnych doświadczeń w mistrzowskim dyskursie [Drama. Creation. Transgression. Spaces of intersubjective experiences in a masterful discourse]. „Przestrzenie Teorii” 36. Poznań 2021, Adam Mickiewicz University Press, pp. 273-290. ISSN 1644-6763. DOI 10.14746/pt.2021.36.16.

The article is a response to the proposal to create a space for discourse on the dramatic dimensions of contemporary humanities. Dramaturgy, creativity and transgression are notions in the master discourse of three women Nobel Prize winners. The basis for the text is the issues contained in the speeches given by these Nobel Prize-winning authors. The intersubjective discourse around humanistic concerns about the changes in the present regards the limits of creation, the process of creative transgressions in designing the world and the potential in the space of sense-creating experiences. It shows a vision of a human who "thinks through creativity, sees the world differently". Transgressive activity allows us to transform reality, and going beyond the boundaries is like successive acts of creating, or at least the creation of the world.
\end{abstract}

KEYWORDS: drama, creativity, transgression, intersubjektivity, Nobel Prize

\section{Wprowadzenie}

Wskazane w tytule opracowania określenia stanowią swoistą matrycę pojęciowa, która znajduje zastosowanie w refleksji teoretycznej i empirycznych eksploracjach naukowych. Różnorodność zastosowań określeń z obszaru dramaturgii (dramatyczności), twórczości czy transgresyjności zwiększa ich wieloznaczność, a to z kolei umożliwia podejmowanie nowych poszukiwań poznawczych. Opracowanie artykułu jest odpowiedzią na propozycję otwartej przestrzeni dla dyskursu nad dramaturgicznymi wymiarami współczesnej humanistyki. Dramaturgia - twórczość - transgresja stanowia pochylenie się nad pojęciami w dyskursie osobliwym - mistrzowskim. Trzy niezwykłe kobiety: Maria Skłodowska-Curie (1867-1934), Wisława Szymborska (1923-2012) i Olga Tokarczuk. Co je łączy?

Maria Skłodowska-Curie to jedyna kobieta, która odebrała Nagrodę Nobla dwukrotnie ${ }^{1}$. W dziedzinie fizyki odebrali ją w 1903 roku Maria

${ }^{1}$ Na dyplomie Nagrody Nobla z 1903 roku widnieje podpis Marie Curie, ale już na dyplomie drugiej Nagrody Nobla z 1911 roku napisano Marie Sklodowska Curie, co według niektórych opinii było zrobione na prośbę samej uczonej. Ciekawy jest fakt, że na stronie 
Skłodowska-Curie i jej mąż Piotr Curie. Osiem lat później, 10 listopada 1911 roku, Królewska Szwedzka Akademia Nauk przyznała Skłodowskiej-Curie Nagrodę Nobla za odkrycie radu i polonu, tym razem w dziedzinie chemii. Komitet Naukowy Chemii Fundacji Nobla ogłosił, że przyznał nagrodę indywidualna, uzasadniając:

W roku 1903 Szwedzka Akademia Królewska miała zaszczyt przyznać pani Nagrodę Nobla z fizyki za udział w odkryciu promieniotwórczości naturalnej. W tym roku Akademia zdecydowała przyznać pani Nagrodę Nobla z chemii w uznaniu wybitnych zasług położonych na polu tej nauki, jakim były odkrycia pierwiastków radu i polonu oraz opisanie cech radu i wyizolowanie go w postaci metalu, a także badania nad związkami tych poszczególnych pierwiastków. Odkąd istnieje Nagroda Nobla, od jedenastu lat, po raz pierwszy zdarza się, że dwukrotnie otrzymuje je ta sama osoba. Proszę to uznać za dowód, że Akademia przywiązuje ogromną wagę do Pani najnowszych odkryć.

W 1996 roku Komitet Noblowski przyznał Nagrodę Nobla w dziedzinie literatury Wisławie Szymborskiej, pisząc w uzasadnieniu: „za poezję, która z ironiczna precyzją pozwala historycznemu i biologicznemu kontekstowi ukazać się we fragmentach ludzkiej rzeczywistości”.

Literacka Nagroda Nobla za 2018 rok, przyznana Oldze Tokarczuk, zawierała następujące uzasadnienie: „za narracyjną wyobraźnię połączoną z encyklopedyczną pasja, co sprawia, że prezentuje, że przekraczanie granic jest formą życia”.

Podstawa opracowania tekstu jest problematyka zawarta w wygłoszonych przemowach obu ${ }^{2}$ autorek. Podjęty dyskurs wokół dramaturgicznych wymiarów współczesności prowadzi do ukazania wizji człowieka i jego doświadczeń.

The Nobel Prize uczoną przedstawiono jako Marie Curie, nie Sklodowska. W języku polskim jako pierwsze podaje się nazwisko rodowe, stąd powinniśmy pisać Maria Skłodowska-Curie. We Francji zwyczaj jest odwrotny, dlatego mamy Marie Curie-Sklodowską czy Irène Joliot-Curie, a nie Curie-Joliot (jest to powszechnie przyjęty zapis nazwiska córki i zięcia uczonej). Sama Maria podpisywała się bardzo różnie, np.: Marie Curie, Madame Curie, Madame Pierre Curie (jako autorka książki L’isotopie et les éléments isotopes, Société de Physique, Paris 1921), Madame Sklodowska Curie (w rozprawie doktorskiej z 1903 roku), Marya Skłodowska-Curie (w rozprawie doktorskiej wydanej w języku polskim), M. Curie, M. Skłodowska-Curie czy też M., M.C. lub MSC (do rodziny podpis bardzo charakterystyczny). Lucjan Biliński w książce Z Mazowsza do sławy paryskiego Panteonu przytacza słowa brata Marii Józefa Skłodowskiego: „Na kamieniu grobowym został wyryty napis zawierający przed nazwiskiem nabytym, francuskim nazwisko jej rodowe według dokładnej pisowni polskiej z «»» przekreślonym pośrodku. Natomiast na grobowcu w Panteonie, zgodnie z francuskim zwyczajem, wyryto już napis Marie Curie-Sklodowska".

${ }^{2}$ Poeta i Świat, odczyt noblowski (Sztokholm, 7 grudnia 1996), [w:] W. Szymborska, Wiersze wybrane. Wybór i układ autorki, Kraków 2000; O. Tokarczuk, Czuły narrator, odczyt noblowski (Sztokholm, 10 grudnia 2019). 


\title{
Dramaturgiczny wydźwięk współczesności w narracjach noblistek
}

\author{
Świat umiera, a my nawet tego nie zauważamy \\ (O. Tokarczuk). \\ Wielkie to szczęście nie wiedzieć doktadnie, na jakim świecie się żyje [...]. \\ $\dot{Z} y$ cie pisze najbardziej oryginalne, najbardziej komiczne, \\ a jednocześnie najbardziej dramatyczne scenariusze
}

(W. Szymborska).

Niczego $w$ życiu nie należy się bać, należy to tylko zrozumieć

(M. Skłodowska-Curie).

Człowiek, zdaniem Romana Ingardena, stoi na skraju dwóch światów: jednego, z którego wyrasta i który przerasta największym wysiłkiem ducha, i drugiego, do którego się zbliża w najcenniejszych wytworach. W żadnym z nich naprawdę nie jest „w domu”. Chcąc utrzymać się na tym skraju, człowiek wydobywa z siebie moc twórczego życia i otacza się nową rzeczywistością. Ta rzeczywistość odsłania mu perspektywy na zupełnie nowe wymiary bytu, ale w tym nowym, przeczuwanym świecie znajduje moce równie mu obce jak świat, z którego pochodzi, i znacznie bardziej go przerastające niż to wszystko, do czego potrafi dorosnąć. W tym jego szczególna rola na świecie, a zarazem ostateczne źródło jego tragicznej, samotnej walki, jego wielu przegranych i jego nielicznych, a prawie zawsze nierozstrzygajacych zwycięstw ${ }^{3}$. Świat w ocenie Olgi Tokarczuk jest niestały i płynny, jego rytm - nieuporzadkowany, a komunikacja - chaotyczna. Autorka nie chce szkicować całościowej wizji kryzysu opowieści o świecie; podkreśla, że często doskwiera jej poczucie, iż światu czegoś brakuje. Mimo że dotarcie do każdej konkretnej informacji jest zdumiewająco łatwe, staje się on nierealny, daleki, dwuwymiarowy, dziwnie nieokreślony. Jest to świat natłoku informacji, sprzecznych ze soba, wzajemnie się wykluczających, „, walczących na kły i pazury". Dostęp do wiedzy miał przynieść ludziom szczęście, dobrobyt, zdrowie i bogactwo. Spełnione marzenia często nas rozczarowują. Okazało się, że nie jesteśmy w stanie unieść ogromu informacji, który zamiast jednoczyć, uogólniać i uwalniać - różnicuje, dzieli, „zamyka w bańkach, tworzy wielość opowieści nieprzystających do siebie albo wręcz wrogich sobie, antagonizujących". Zamiast usłyszeć harmonię świata, usłyszeliśmy kakofonię dźwięków, szum nie do zniesienia. Parafraza Szekspirowskiego cytatu jak

${ }^{3}$ R. Ingarden, Ksiażeczka o człowieku, Kraków 1973, s. 39-40.

275 Dramat. Twórczość. Transgresja 
nigdy pasuje dzisiaj do tej kakofonicznej rzeczywistości: „Internet to coraz częściej opowieść idioty pełna wściekłości i wrzasku”. Tokarczuk stwierdza, że „coś jest ze światem nie tak”. To poczucie, zarezerwowane kiedyś tylko dla neurotycznych poetów, dziś staje się epidemią nieokreśloności i niepokojem. Tokarczuk mówi o cywilizacyjnym regresie, o upośledzeniu umiejętności wielowymiarowego (konkretnego, historycznego, ale i symbolicznego, mitycznego) uczestniczenia w łańcuchu wydarzeń zwanym życiem ${ }^{4}$.

Chwilami życie bywa znośne - mówi Wisława Szymborska - żyjemy dłużej, ale mniej dokładnie i krótszymi zdaniami. Myśląc o świecie, jesteśmy zatrwożeni jego ogromem i własną wobec niego bezsilnościa, rozgoryczeni jego obojętnością na cierpienia - ludzi, zwierząt, a może i roślin, bo skąd pewność, że rośliny są od cierpień wolne? Świat jest bezmiernym teatrem, do którego mamy wprawdzie bilet wstępu, ale ważność tego biletu jest śmiesznie krótka, ograniczona dwiema stanowczymi datami. Szymborska stwierdza, że cokolwiek pomyślelibyśmy o świecie - jest on zadziwiajacy. Ale w określeniu ,zadziwiający” kryje się pewna logiczna pułapka. Zadziwia nas przecież to, co odbiega od jakiejś znanej i powszechnie uznanej normy, od jakiejś oczywistości, do której jesteśmy przyzwyczajeni. Zdaniem Szymborskiej takiego oczywistego świata nie ma wcale.

Tokarczuk zauważa, że świat został sprowadzony do statusu przedmiotu, który można ciąć na kawałki, wykorzystywać i niszczyć. Doprowadziły do tego chciwość, brak szacunku do natury, egoizm, brak wyobraźni, niekończące się współzawodnictwo oraz brak odpowiedzialności. W rezultacie świat umiera, a my nawet tego nie zauważamy ${ }^{5}$. Świat staje się zbiorem rzeczy i wydarzeń, martwą przestrzenia, w której poruszamy się samotni i zagubieni, zniewoleni niezrozumiałym fatum, poczuciem bycia igraszka wielkich sił historii czy przypadku. Tokarczuk stwierdza, iż zaczynamy widzieć świat we fragmentach, w kawałkach odległych od siebie niczym galaktyki, a rzeczywistość, w jakiej żyjemy, upewnia nas w tym. Wszystko jest od siebie oddzielone, żyje osobno, bez związku. Tokarczuk mówi także o zmianach dokonujących się w sferze ludzkiej duchowości - w kategoriach zaniku albo powierzchowności i rytualności ${ }^{6}$.

${ }^{4}$ Jak argumentował E. Fromm, życie nie ma innego znaczenia poza tym, jakie nadaje mu człowiek, który rozwija, uzewnętrznia i aktualizuje swoje możliwości (E. Fromm, Mieć czy być, Poznań 1999, s. 43).

${ }^{5}$ Wobec takiej argumentacji warto byłoby przypomnieć słowa H.-G. Gadamera o aktualności piękna: „Piękno [...] jest czymś w rodzaju rękojmi, iż w całym zamęcie rzeczywistości [...] to, co prawdziwe, nie leży w niedostępnej dali, ale wychodzi nam na spotkanie [...]. Piękno spełnia się w postaci samookreślenia i oddycha radością samoprezentacji” (H.-G. Gadamer, Aktualność piękna. Sztuka jako gra, symbol i święto, Warszawa 1993, s. 18-20).

${ }^{6}$ Józef Kozielecki dostrzega ścisły związek pomiędzy sensem życia a religijną transcendencją i jako obserwator przemian w dzisiejszym świecie stwierdza, że współczesnemu 


\section{Twórczość jest sposobem spostrzegania świata ${ }^{7}$}

Twórczość ${ }^{8}$ jest dla człowieka „próba, jak dalece może on być aktywny, «intensywny», jak dalece może zaznaczyć swoje istnienie w świecie tak, aby pozostał po nim ślad trwały" zewnętrznego świata, jego interioryzacji i transformacji systematycznie wzbogacają widzenie rzeczywistości, tworząc przy tym formy zupełnie niezależne od wzorów natury, a także od poprzednich form sztuki już istniejącej. Siła sprawcza jest w każdym przypadku istota ludzka, niezależnie od tego, jaki jest udział świadomości twórcy w procesie tworzenia dzieła ${ }^{10}$. "Człowiek nie godzi się na stagnację i trwanie w tajemnicy, ale poszukuje, i mimo że niekiedy błądzi, nadal poszukuje i zbliża się do prawdy w tym nieskończonym procesie przyswajania i przemienności"11.

Otwarte pytania sztuki wyznaczają takie jej przeżycie ${ }^{12}$, które Jerome Bruner określił jako skuteczne zdziwienie: „Triumf skutecznego zdziwienia polega na tym, że otwiera przed nami perspektywy oryginalnego przeżywa-

człowiekowi bardziej potrzebna jest nowa etyka niż nowa technika. Aby podejmować i wypełniać zadania życiowe, człowiek wielokrotnie musi przekraczać siebie, czyli dokonywać w sobie wysiłku osobowej transgresji (J. Kozielecki, Z Bogiem albo bez Boga. Psychologia religii - nowe spojrzenie, Warszawa 1991).

7 „Myśląc sztuka, świat zobaczymy inaczej” - nawiązanie do słów Anny Krajewskiej. Zob. Dramaturgia sztuki, „Przestrzenie Teorii” 2019, 31, s. 7-12.

8 Twórczość może być rozpatrywana w obrębie czterech kategorii: jako dzieło (wytwór), proces, zespół specyficznych cech osobowości bądź zespół zdolności i uzdolnień, zespół stymulatorów społecznych (społeczny klimat uwarunkowań twórczości). Zob. E. Nęcka, Psychologia twórczości, Gdańsk 2001; S. Popek, Człowiek jako jednostka twórcza, Lublin 2001; A. Strzałecki, Twórczość a style rozwiqzywania problemów praktycznych. Ujęcie prakseologiczne, Wrocław 1989.

${ }^{9}$ M. Gołaszewska, Twórczość a osobowość twórcy. Analiza procesu twórczego, Lublin 1958.

${ }^{10}$ Psycholog twórczości, malarz i literat, prof. dr hab. Stanisław Popek. Jego przesłaniem w działalności naukowej, dydaktycznej i artystycznej jest przekonanie, że człowiek jest przede wszystkim jednostką twórcza, że „słowo «twórca» jest synonimem słowa «człowiek», a «twórczość» jest nierozerwalnie związana z istotą ludzką" (S. Popek, Barwy i psychika. Percepcja. Ekspresja. Projekcja, Lublin 2012, s. 48; Człowiek jako jednostka twórcza, Lublin 2001; Psychologia twórczości plastycznej, Kraków 2010).

${ }^{11}$ S. Popek, Człowiek jako jednostka twórcza, ed. cit., s. 9. Twórczość istnieje niezmiennie jako aktualna i żywa: „Sny o wielkości odchodzą w nieznane. Boleść przemienia się w popiół zapomnienia. Pozostaje piękno" (S. Popek, Do Michała Anioła, [w:] idem, Tryptyk z Michałem Aniołem, Lublin 1997).

12 Świat symboliczny stanowi odzwierciedlenie świata wewnętrznego, a przez doświadczenie symboliczności rozumiemy, że „to, co jednostkowe, szczególne jest niczym ułamek bytu, że coś, co z nim koresponduje, jest obietnicą uzupełnienia całości i szczęścia, albo też że ta wciąż poszukiwana cząstka jest drugim odłamkiem pasującym do naszego fragmentu życia [...]. Symboliczny charakter sztuki oznacza nieskończony proces interpretacji. Sztuka staje się grą odkrywania i skrywania znaczenia” (H.-G. Gadamer, op. cit., s. 61-62). 
nia świata. Jest w tym skutecznym zdziwieniu fascynacja i radość, ale jest także często dotkliwe uczucie niepokoju. Jest miejsce na zachwyt i miłość do świata, ale i na grozę i przerażenie, które ten świat wzbudza"13.

Władysław Stróżewski podkreśla dialektyczność procesu twórczego. Dialektyka jest obecna we wszystkim, co dzieje się w ramach procesu twórczego, pełnego sprzeczności, napięć, konfliktów. Z niej wyłania się nowy byt, jego istota i wartość. Jedność procesu twórczego nie tylko nie wyklucza, lecz przeciwnie - umożliwia występowanie w jego ramach całego zespołu opozycji: determinizm-konieczność, konsekwencja-nieprzewidywalność, poddanie-dominacja, spontaniczność-kontrola, bezpośredniość-pośredniość, swoboda-rygor, improwizacja-kalkulacja, akceptacja-odrzucanie, nowatorstwo-perfekcjonizm, stwarzanie-odkrywanie. Można powiedzieć, że dialektyka jest naczelną cechą ontologiczną procesu twórczego, że wręcz wyznacza charakter jego stawania się ${ }^{14}$. Wyobraźnia - ekspresja - twórczość sa to kategorie nie tyle wewnętrznego autonomicznego świata jednostki, ile - jak dowodzi Irena Wojnar - jej nowego stosunku do rzeczywistości zewnętrznej. Przygoda spotkania umysłu ze światem pozwala równocześnie na akt osobistej ekspresji i na zobiektywizowany akt twórczy, stanowiący również przetwarzanie samego podmiotu. Ekspresja i twórczość stają się równocześnie narzędziami pełniejszego poznawania świata, osobistym jego przyswajaniem. Wymiar estetycznej samowiedzy człowieka wiąże się z jego odwiecznym dramatyzmem i wyraża się w symbolice stłuczonego zwierciadła oraz jego niezliczonych okruchów. Chwieje się uporządkowany obraz świata, w miarę jak zwielokrotnia się liczba zwierciadeł, które ostatecznie okazują się jedynie ułamkami odbitych rozczarowań. Jedność zharmonizowanego obrazu świata przestaje istnieć, a jej odbicie staje się kolejnym źródłem lęków i niepokoju ${ }^{15}$.

Literatura - zdaniem Olgi Tokarczuk - stała się więc polem wymiany doświadczeń, agora, na której każdy może opowiedzieć swój los albo oddać głos swojemu alter ego. Jest to przy tym przestrzeń demokratyczna - każdy może się wypowiedzieć, każdy może też dokonać kreacji „głosu, który mówi”.

${ }^{13}$ J. Bruner, O poznawaniu. Szkice na lewa ręke, przeł. E. Krasińska, Warszawa 1971, s. 40.

${ }^{14}$ W. Stróżewski, Dialektyka twórczości, Kraków 1983, s. 260.

${ }^{15}$ I. Wojnar, Trzy wymiary estetycznej samowiedzy człowieka, „Sztuka i Filozofia” 1994, 8, s. 88-89. Sztuka pełni funkcję porządkującą i informacyjną. Tworzenie przez sztukę nowej rzeczywistości, przedmiotowej i symbolicznej, stanowi propozycję, interpretację i antycypację, przyczynia się do lepszej orientacji człowieka w zmieniającym się świecie i ułatwia otwarcie na to, co nadchodzi. Zachęca do „widzenia razem, do przekraczania pokawałkowanego obrazu świata na rzecz jego wizji syntetycznej, wynikającej z możliwości postrzegania faktów i zjawisk w ich kontekstach i strukturach, w ich wzajemnych uwarunkowaniach. Ten aspekt estetycznej samowiedzy wyraża się w afirmacji istoty człowieczeństwa” (ibidem, s. 82). 
Tokarczuk przyznaje, iż cieszy ją to, że literatura cudownie zachowała sobie prawo do wszelkich dziwactw, fantasmagorii, prowokacji, groteski i wariactwa. Pisarkę fascynuje kojarzenie faktów, szukanie porządków. Jest przekonana, że pisarski umysł jest umysłem syntetycznym, który z uporem zbiera wszystkie okruchy i próbuje z nich na nowo skleić „uniwersum całości”. Tworzenie opowieści jest niekończącym się ożywianiem, nadawaniem istnienia tym wszystkim okruchom świata, jakimi są ludzkie doświadczenia, przeżyte sytuacje, wspomnienia ${ }^{16}$. Literatura - zawierając w sobie elementy poznawcze, jakimi sa zdziwienie, ciekawość, otwartość - stawia pytania i nieustannie poszukuje na nie odpowiedzi.

Tworzenie według Szymborskiej polega na tym, że „się wyszarpuje jakąś cząstkę rzeczywistości [...]. Poezja musi przekroczyć oczywistość, musi dawać jej inny wymiar”. Człowiek twórczy powinien „sam na sam mocować się ze światem. Nie znaczy to, żeby nie miał ideałów, ale będzie lepiej dla jego twórczości, jeśli te ideały nie ułożą mu się nigdy w zwarty, nieprzepuszczalny system".

We wspomnieniach o matce Ewa Curie napisała:

Wielki triumf umysłu i siły woli, żelaznego uporu i konsekwencji w wytrwałych, niemal nadludzkich wysiłkach, a także tej bezwzględnej, prawie z manią graniczącej wewnętrznej potrzeby, by wszystko, co robi, robić jak najlepiej można. Namiętnie zaczyna kochać tę jedyną w świecie atmosferę skupienia, ciszy i jakiegoś specjalnego fanatyzmu pracy: atmosferę laboratoriów, która odtąd do końca życia będzie jej droższa nad wszystko ${ }^{17}$.

\section{Transgresyjny wymiar twórczości. Granice doświadczenia człowieka}

Psychologia humanistyczna i egzystencjalna podkreśla zdolność jednostki do przekraczania stanów aktualnych i wychodzenia poza obiektywnie istniejąca rzeczywistość jako aspekt ludzkiego istnienia ${ }^{18}$. Stany trans, czyli przechodzenie, wychodzenie poza (transcendencja, autotranscendencja), sa szczególną właściwością człowieka, ukazująca jego wyjątkowe możliwości (Maslow, 1986, 1987; Rogers, 2002). Transgresję jako rozwój osoby w róż-

${ }^{16}$ „Między wiarą a poznaniem, wątpieniem a pewnością, pewność jest tylko pragnieniem. Wątpieniem staje się każda pewność" (S. Popek, Nić Adriadny, [w:] idem, Srebrne ogrody, Lublin 2003).

${ }^{17}$ Maria Curie i córki. Listy, przeł. T. Pogwizd, M. Mendychowski, Wrocław 2011, s. 84.

${ }^{18}$ A. Gałdowa, Powszechność i wyjatek, Kraków 2000; M. Opoczyńska, Wprowadzenie do psychologii egzystencjalnej, Kraków 1999. 
nych wymiarach psychologicznych ujmował A.H. Maslow ${ }^{19}$. Zauważył on, że w trakcie zaspokojenia potrzeby samorealizacji osoba może przekroczyć swój dotychczasowy potencjał rozwoju psychologicznego i duchowego:

Wydaje się zupełnie oczywiste, że potrzeba przekraczania granic ego może być potrzebą w tym samym znaczeniu, w jakim potrzebujemy witamin i minerałów, to znaczy jeśli potrzeba nie jest zaspokojona, człowiek staje się chory w taki czy inny sposób. Trzeba powiedzieć, że jednym z najbardziej zadowalających i najpełniejszych przykładów transcendencji ego jest zdrowy związek miłości ${ }^{20}$.

„Transgresja jest gestem dotyczaccym granicy: tu, w cienkiej linii, objawia się błyskawica jej przejścia, [...] Grą transgresji... zdaje się rządzić... upór: transgresja przekracza i nie przestaje ustawicznie przekraczać linii [...] aż po horyzont nieprzekraczalnego. Afirmuje ona ograniczony byt, afirmuje bezgraniczność [...] żadna granica nie może jej utrzymać"21. Estetykę granicy można rozpatrywać w kontekście kanonów piękna, ale także wiary i wiedzy, wiary i niewiary, prawdy i fałszu, wyobraźni i pamięci, trwania (ciagłości) i zmiany ${ }^{22}$. Ryszard Nycz pisze w Poetyce doświadczenia.... „Literatura staje się tutaj świadectwem ludzkiego dążenia do transgresji, które nie wzdraga się przed żadnym konfliktem, a równocześnie zapewnia poczucie bezpieczeństwa płynące $\mathrm{z}$ władzy tworzenia nowych znaczeń i odkrywania nieprzewidywalnych możliwości”" ${ }^{23}$. Granice z jednej strony ograniczaja wolność i swobodę działań człowieka, który pragnie realizować swoje cele i powodować zmiany, z drugiej zaś gwarantują poczucie spełnienia. W ujęciu Józefa Kozieleckiego - twórcy koncepcji transgresyjnej człowieka ${ }^{24}$ - istotę transgresji stanowią doświadczenie granicy i jej przekraczanie, ,intencjonalne wychodzenie człowieka poza to, czym jest i co posiada, wyrasta ponad siebie. Granica pełni dwie komplementarne funkcje. Z jednej strony oddziela istniejący stan rzeczy od stanu antycypowanego. Dokonuje podziału całości na znane i nieznane, określone i nieokreślone, zagospodarowane i niezagospodarowane przez człowieka. Wyznacza przestrzeń nieosiagalna, niedotknięta, wyobrażona, przewidywana jedynie intuicyjnie. Z drugiej strony ułatwia człowiekowi spostrzeganie całości, motywuje do jej opanowania,

${ }^{19}$ A.H. Maslow, Motywacja i osobowość, Warszawa 1999.

${ }^{20}$ Ibidem, s. 267.

${ }^{21}$ M. Foucault, Przedmowa do transgresji, [w:] Osoby. Transgresje 3, red. M. Janion, S. Rosiek, Gdańsk 1984, s. 305-307.

${ }^{22}$ M. Gołaszewska, T. Gołaszewski, Estetyka granicy, Kraków 2010.

${ }^{23}$ R. Nycz, Poetyka doświadczenia. Teoria - nowoczesność - literatura, Warszawa 2012, s. 135 .

${ }^{24}$ J. Kozielecki, Koncepcja transgresyjna człowieka. Analiza psychologiczna, Warszawa 1987, s. 13. 
zdobycia tego, co po drugiej stronie, a następnie redefinicji pełni doświadczenia w nowy i twórczy sposób" (Kozielecki, 2002). Adaptacyjny potencjał podmiotu oznacza dostosowanie działania do warunków wyznaczonych przez charakter otoczenia, a transgresyjny potencjał podmiotu określa, czy generowane przez jednostkę działania są podatne na twórczą modyfikację ${ }^{25}$. Transgresyjna aktywność człowieka ma głównie charakter adaptacyjny, służy przystosowywaniu się do niestabilnych warunków i wymagań otoczenia.

Zdaniem Tokarczuk ekspresja autorskiego ,ja” nie daje gwarancji uniwersalności. Brakuje nam parabolicznego wymiaru opowieści. Bohater paraboli jest bowiem zarazem soba, człowiekiem żyjącym w określonych warunkach historycznych czy geograficznych, a jednocześnie wykracza daleko poza ten konkret, stając się Każdym i Wszędzie. W wymagającym psychologicznie zabiegu parabola, znajdując dla różnych losów wspólny mianownik, uniwersalizuje nasze doświadczenie, a jej niedostateczna obecność jest świadectwem bezradności ${ }^{26}$. Życie tworzą wydarzenia, lecz dopiero wtedy, gdy potrafimy je zinterpretować, próbować zrozumieć i nadać im sens, zamieniają się one w doświadczenie. Doświadczenie jest faktem poddanym interpretacji i umieszczonym w pamięci. Odwołuje się do głębokiej struktury znaczeń, na której potrafimy rozpiać nasze życie i dokładnie mu się przyjrzeć. Poetkę zastanawia możliwość znalezienia podwalin pod nową opowieść, która będzie uniwersalna, całościowa, niewykluczająca a zakorzeniona w naturze, pełna kontekstów i jednocześnie zrozumiała.

\section{Proces twórczych transgresji w projektowaniu świata}

O granicznym charakterze ludzkiej egzystencji pisze Georg Simmel, przyjmując za punkt wyjścia do decydującego sensu w filozofii życia: „Ist-

${ }^{25}$ Takiemu spojrzeniu odpowiada pozytywna wizja człowieka jako podmiotu stającego się: od ujawniania posiadanych zasobów i aktualizowania potencjałów - poprzez ich twórcze realizacje - do przekraczania granic (w) samorealizacji. Tak ujmowana perspektywa tworzy warunki optymalizacji rozwoju człowieka i pozwala również na poszerzanie granic Ja: przez proces samorealizacji - do działań transgresyjnych - i twórczych kompetencji. Humanistyczny paradygmat twórczości został przyjęty w autorskim projekcie badań nad twórczym charakterem kompetencji osób dorosłych. Tworzy on przestrzeń dla rozwoju, ujmowanego jako zespół kompetencji sprzyjających samorealizacji. Oznacza najlepsze wykorzystanie możliwości podmiotowych w określonych warunkach życiowych. Zob. M. Wróblewska, Kompetencje twórcze w dorostości, Białystok 2015.

${ }^{26}$ „Z perspektywy dynamicznej w ostatecznym rachunku wszelkie wybory są w rzeczywistości mądre, jeśli tylko zgodzimy się na dwa rodzaje mądrości: mądrość ukierunkowaną na rozwój i mądrość ukierunkowaną na obronę. [...] Obronność może być równie mądra jak odwaga; zależy to od poszczególnej osoby, jej specyficznego statusu i szczególnej sytuacji, w której ma dokonywać wyboru" (A.H. Maslow, W stronę psychologii istnienia, WarszawaPoznań 1986, s. 313). 
nienie granicy jako takiej jest konieczne, ale każda konkretna granica może zarazem zostać przekroczona, każde ustalenie przesunięte, każda bariera rozsadzona; akt przekroczenia ustanawia każdorazowo nowa granicę" ${ }^{27}$. Twórczość jest specyficzną formą działań transgresyjnych. Wiąże się z intencjonalna zmiana, której istota jest rozwiazywanie nowych problemów o charakterze naukowym, artystycznym, praktycznym czy organizacyjnym. Proces twórczy jest heurystyczny, nie podlega szczegółowemu planowaniu i często prowadzi do nieoczekiwanych rezultatów ${ }^{28}$. Koncepcja transgresyjna charakteryzuje dwa modele twórczości: model konfliktowy (forma obrony przed wewnętrznymi konfliktami i frustracja) oraz model spełnienia (przejaw aktualizacji i samourzeczywistnienia potencjału jednostki), traktując je jako komplementarne. Twórczość może być traktowana jako specyficzny rodzaj ekspansji, poszerzający granice poznania i zakres wiedzy o świecie ${ }^{29}$. Zatem mamy do czynienia z sytuacja, w której człowiek się znajduje, a jednocześnie jest to sytuacja, którą człowiek tworzy. Człowiek w tak definiowanej sytuacji może ujawniać dwie formy własnego istnienia: być jej elementem sytuacji i być jej podmiotem. Traktując człowieka jako podmiot sytuacji, należy podkreślić znaczenie jego twórczej aktywności własnej, która nadaje doświadczeniom poczucie sensu i afirmacji oraz chroni przed niszczącym życie rozczarowaniem. Marzą mi się - mówi Tokarczuk - wysokie punkty widzenia i szerokie perspektywy, w których kontekst wykracza daleko poza to, czego moglibyśmy się spodziewać. Odkrycie „efektu motyla” kończy, według narracji Tokarczuk, epokę niezachwianej ludzkiej wiary we własną sprawczość, zdolność kontroli w świecie. „Efekt motyla” polega na tym, że minimalne zmiany w warunkach początkowych jakiegoś procesu mogą dać w przyszłości kolosalne i nieobliczalne rezultaty. Człowiek pozostaje zaledwie cząstką tych procesów. Nie odbiera to jego mocy jako budowniczego, zdobywcy i wynalazcy, uzmysławia jednak, że rzeczywistość jest bardziej skomplikowana, niż kiedykolwiek mogło się człowiekowi wydawać.

Świat jest tkanina, którą przędziemy codziennie na wielkich krosnach informacji. Dziśs zasięg pracy tych krosien jest ogromny - za sprawą internetu prawie każdy może brać udział w tym procesie. Problem polega na tym, że nie mamy jeszcze gotowych narracji nie tylko na przyszłość, lecz nawet na konkretne „teraz”, na ultraszybkie przemiany dzisiejszego świata. Brakuje nam języka, punktów widzenia, metafor, mitów i nowych baśni. Żyjemy w rzeczywistości wielogłosowych narracji pierwszoosobowych, jako

${ }^{27}$ G. Simmel, Filozofia życia: cztery rozdziaty metafizyczne, Warszawa 2007.

${ }^{28}$ J. Kozielecki, Koncepcja transgresyjna cztowieka..., ed. cit.

${ }^{29}$ Granica stanowi „linię demarkacyjną oddzielającą to, czym człowiek jest i co posiada, od tego, czym jeszcze nie jest, ale czym może być dzięki działaniom transgresyjnym” (ibidem, s. 48$)$. 
rodzaj opowieści, który zatacza wąskie kręgi wokół „ja” twórcy. Ten rodzaj zindywidualizowanego punktu widzenia jest najbardziej naturalny, ludzki, uczciwy, jednakże oznacza budowanie opozycji ,ja” i „,świat”, a ta bywa alienująca. Tokarczuk mówi o poszukiwaniu w życiu momentu, w którym wszystko stało się inne, mniej zniuansowane, prostsze. Odkąd szept świata umilkł, zastapiły go hałasy miasta, szmer komputerów, grzmot przelatujących nad głową samolotów i męczący biały szum oceanów informacji. Wobec tych warunków poetka wierzy, że musi opowiadać o świecie i ludziach z c z u łości a , będącą sztuką uosabiania, współodczuwania, a więc nieustannego odnajdowania podobieństw. Czułość personalizuje to wszystko, do czego się odnosi. Jest najskromniejszą odmiana miłości. Pojawia się tam, gdzie z uwagą i skupieniem zaglądamy w drugi byt, w to, co nie jest „ja”. Czułość jest spontaniczna i bezinteresowna, wykracza daleko poza empatyczne współodczuwanie. Jest raczej świadomym, choć może trochę melancholijnym współdzieleniem losu.

Poeta, jeśli jest prawdziwym poeta - zaznacza Szymborska - musi ciagle powtarzać sobie: „nie wiem”. Każdym utworem próbuje na to odpowiedzieć, ale kiedy tylko postawi kropkę, wówczas ogarnia go wahanie i zaczyna zdawać sobie sprawę z tego, że jest to odpowiedź tymczasowa i absolutnie niewystarczająca. Próbuje więc jeszcze raz, aby te dowody niezadowolenia z siebie historycy literatury spięli potem spinaczem i nazwali „dorobkiem”.

Literatura zaczyna się od owego „dlaczego?”, nawet jeśli mielibyśmy na to pytanie, zdaniem Tokarczuk, odpowiadać bez przerwy zwyczajnym „nie wiem”. Literatura jest jedną z niewielu dziedzin, które próbują nas przytrzymać przy konkrecie świata. Opowieść jest więc porządkowaniem w czasie nieskończonej ilości informacji, ustalaniem ich związków z przeszłościa, teraźniejszością i przyszłościa, odkrywaniem ich powtarzalności oraz układaniem ich w kategoriach przyczyny i skutku. Tylko literatura jest w stanie pozwolić nam wejść głęboko w życie drugiej istoty, rozumieć jej racje, dzielić jej uczucia, przeżyć jej los.

Dlatego tak wysoko cenię sobie - stwierdza Szymborska - dwa małe słowa: „nie wiem”. Małe, ale mocno uskrzydlone. Rozszerzające życie na obszary, które mieszczą się w nas samych, i obszary, w których zawieszona jest nasza nikła Ziemia. „Gdyby Maria Skłodowska-Curie nie powiedziała sobie «nie wiem», zostałaby pewnie nauczycielka chemii na pensji dla panienek z dobrych domów i na tej - skądinąd zacnej - pracy upłynęłoby jej życie. Ale powtarzała sobie «nie wiem» i te właśnie słowa przywiodły ja, i to dwukrotnie, do Sztokholmu, gdzie ludzi o duchu niespokojnym i wiecznie poszukującym nagradza się Nagrodą Nobla".

Jedną z najcięższych ludzkich niedoli, wedle Szymborskiej, jest praca nielubiana, która nudzi, ceniona tylko dlatego, że nawet w tej postaci nie 
dla wszystkich jest dostępna. Najbliższe stulecia zapewne nie przyniosa $\mathrm{w}$ tej kwestii zmiany ${ }^{30}$. W odczycie noblowskim - w słowach kończących przemówienie - Szymborska odniosła się do poezji i roli poetów:

Zgoda, w mowie potocznej, która nie zastanawia się nad każdym słowem, wszyscy używamy określeń: „zwykły świat”, „zwykłe życie”, „zwykła kolej rzeczy”... Jednak w języku poezji, gdzie każde słowo się waży, nic już zwyczajne i normalne nie jest. Żaden kamień i żadna nad nim chmura. Żaden dzień i żadna po nim noc. A nade wszystko żadne niczyje na tym świecie istnienie. Wygląda na to, że poeci będą mieli zawsze dużo roboty ${ }^{31}$.

Nie wierzę - mówi Szymborska - aby poezja mogła zmienić świat. Prawdziwi twórcy zła nie czytają wierszy. W jednym z fragmentów wywiadu zapytana o to, co w życiu jest ważne, odpowiedziała: „Szczegóły. Detale. Prostota. Ta uczuć, krajobrazu, czynności. Spokój. No i żeby ze stosunkowo niskim poziomem żalu odchodzić. Wiadomo, że zawsze będziemy odchodzili niepogodzeni, ale chciałabym móc powiedzieć: No okejos, Panie Boże, w miarę było. Chodźmy. [...] Ważne, żeby wykorzystać, co się dostało, nie przepieprzyć tego. Nic więcej nie dostaniemy”. Tworzenie opowieści jest niekończącym się ożywianiem, nadawaniem istnienia tym wszystkim okruchom świata, jakimi są ludzkie doświadczenia, przeżyte sytuacje, wspomnienia.

\section{Różnorodność światów transgresji}

„Transgresja nie jest tylko terminem naukowym - jest losem człowieka”32. Ze względu na treść celów jednostkowych można wyodrębnić następujące rodzaje transgresji: działania skierowane na świat fizyczny (,ku rzeczom”), działania skierowane ku ludziom (,ku innym”), działania symboliczne (,ku symbolom”) oraz działania autokreacyjne (,ku sobie”) ${ }^{33}$.

„Czy możliwa jest taka opowieść, która wyszłaby poza niekomunikatywne więzienie własnego «ja», odsłoniła większy obszar rzeczywistości

${ }^{30}$ „Twoja praca wypełni dużą część twojego życia i jedyny sposób na to, aby być prawdziwie spełnionym, to robić to, co wierzysz, że jest świetną robota. A jedyny sposób na robienie świetnej roboty to kochanie tego, co robisz. Jeśli jeszcze tego nie znalazłeś, szukaj dalej. Nie spoczywaj” (S. Jobs, fragmenty przemówienia wygłoszonego 12 czerwca 2005 roku do studentów Uniwersytetu Stanforda, [w:] W. Isaacson, Steve Jobs, Warszawa 2011).

${ }^{31}$ Poeta $i$ Świat, odczyt noblowski (Sztokholm, 7 grudnia 1996), [w:] W. Szymborska, Wiersze wybrane, ed. cit.

${ }^{32}$ J. Kozielecki, Z Bogiem albo bez Boga..., ed. cit., s. 31.

${ }^{33}$ Idem, Koncepcja transgresyjna człowieka..., ed. cit.; idem, Transgresja i kultura, Warszawa 2002. 
i ukazała wzajemne związki?” - pyta Tokarczuk. „Marzy mi się język, który potrafi wyrazić najbardziej niejasną intuicję, marzy mi się metafora, która przekracza kulturowe różnice, i w końcu gatunek, który stanie się pojemny i transgresyjny” ${ }^{34}$. „Niczego w życiu nie należy się bać, należy to tylko zrozumieć. Jestem z tych, którzy wierza, że nauka jest czymś bardzo pięknym" - mówiła Maria Skłodowska-Curie. Niezwykła biografia noblistki jest przykładem transgresji dokonywanych na wszystkich polach jej aktywności: związanych ze zdobywaniem wiedzy, w zakresie nauki, w zakresie społecznej praktyki, transgresji organizacyjnych. Przestrzenie kluczowe dla transgresji Marii Skłodowskiej-Curie stanowił „świat symboliczny”, w którym dokonywała odkryć, tworząc nowe idee, niekonwencjonalne konstrukcje myślowe i wyobrażeniowe ${ }^{35}$. Transgresjami w zakresie nauki były najpierw odkrycia w dziedzinie fizyki i badanie zjawiska promieniotwórczości (rok 1903) ${ }^{36}$. Osiagnięty sukces nie oznaczał zakończenia drogi tworzenia. Okazało się bowiem, że „transgresja rodzi transgresję" ${ }^{37}$. Maria Skłodowska-Curie kilka lat później odebrała kolejnego Nobla - tym razem $\mathrm{w}$ dziedzinie chemii, za wydzielenie radu. W prowadzonych przez siebie eksperymentach wypróbowywała „dziesiątki substancji z dokładnościa, która [...] stała się naukową obsesją"38. Transgresje przyjmowały postać transgresji historycznych $(\mathrm{H})$, przekraczania granic, których nikt dotychczas nie przekroczył, o największym stopniu nowości i oryginalności. Działania zrewolucjonizowały dotychczasowa wiedzę z dziedziny fizyki i chemii, stały się podstawami zmiany paradygmatu nauki. Maria Skłodowska-Curie jako pierwsza w historii kobieta objęła katedrę na Sorbonie ${ }^{39}$. To pierwsza i jedyna kobieta wybrana jednogłośnie do paryskiej Akademii Medycznej;

${ }^{34}$ O. Tokarczuk, Czuty narrator, odczyt noblowski (Sztokholm, 10 grudnia 2019), s. 22.

${ }^{35}$ J. Kozielecki, Transgresja i kultura, ed. cit.

${ }^{36}$ W 1903 roku do Nagrody Nobla w dziedzinie fizyki nominowano Henriego Becquerela oraz Piotra Curie, a kandydatura Marii wywołała sprzeciw. Piotr Curie wystosował list do fizyka Henriego Poincarégo, w którym pisał: „Byłby to dla mnie wielki zaszczyt, ale bardzo chciałbym dzielić go z małżonka. Pragnąłbym, żebyśmy byli uhonorowani razem, tak jak razem pracowaliśmy. Pani Curie badała promieniotwórcze własności soli uranu i toru oraz minerałów radioaktywnych. To ona podjęła trud chemicznego badania nowych pierwiastków i przeprowadziła wszystkie niezbędne frakcjonowania, by wyizolować rad, a także ustaliła masę atomową tego metalu. Brała również udział w badaniach nad promieniowaniem i odkryciu radioaktywności indukowanej”.

${ }^{37}$ J. Kozielecki, Społeczeństwo transgresyjne. Szanse i ryzyko, Warszawa 2004, s. 129.

${ }^{38}$ D. Brain, Rodzina Curie. Nigdy nie opowiedziana historia życia prywatnego i pracy najbardziej kontrowersyjnej rodziny $w$ dziejach nauki, Warszawa 2005, s. 61.

${ }^{39}$ Komisja, która nadała jej na Sorbonie tytuł doktora nauk ścisłych (1904), wyraziła pogląd, że „przedstawione wyniki stanowią największy naukowy wkład kiedykolwiek wzniesiony przez pracę doktorską" (ibidem, s. 79). 
cudzoziemka, której szczątki spoczęły w paryskim Panteonie. W ten sposób „transgresje kształtują biografie jednostek, dzieje instytucji, historię narodu i kultury" ${ }^{40}$. Córka Irena otrzymała kondolencje od prezydenta RP Ignacego Mościckiego, który napisał: „Polska traci w ś.p. Pani Curie-Skłodowskiej nie tylko uczona, która imię swej ojczyzny wsławiła w całym świecie, ale i wielką obywatelkę, zawsze przez całe życie czujnie stojącą na straży in-

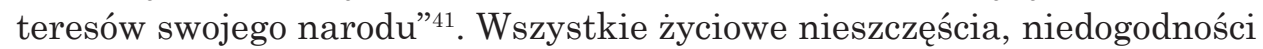
i upokorzenia paradoksalnie stymulowały działania transgresyjne. Życie Skłodowskiej-Curie od chwili uzyskania przez nią pierwszej Nagrody Nobla upływało między transgresją a zmaganiem się z doświadczeniami epifanicznymi - przełomowymi. Co jest niezwykłe w biografii Skłodowskiej-Curie działania transgresyjne były motywowane ogromną potrzebą zdobywania wiedzy i bezkompromisowym poszukiwaniem prawdy, co oznacza również zaspokojenie potrzeby hubrystycznej: „,...] Taka drabina perfekcji nie ma końca. W tym wypadku o sukcesie lub niepowodzeniu nie decydują w zasadzie opinie innych, ale własne aspiracje i wewnętrzne standardy mistrzostwa. Standardy te sa często tak wysokie, tak prometejskie, że sprostanie im okazuje się nierealne" ${ }^{42}$.

\section{Potencjał tworzenia (sensotwórczych doświadczeń)}

W słowach Tokarczuk wybrzmiewa swoisty dyskurs wokół definiowania i nadawania znaczeń doświadczeniu człowieka: „Kiedy zmienia się ta opowieść - zmienia się świat. To, jak myślimy o świecie i - co chyba ważniejsze - jak o nim opowiadamy, ma więc olbrzymie znaczenie. Coś, co się wydarza, a nie zostaje opowiedziane, przestaje istnieć i umiera". Dziś problem polega na tym, że nie mamy jeszcze gotowych narracji nie tylko na przyszłość, lecz nawet na konkretne „teraz”, na ultraszybkie przemiany dzisiejszego świata. Nieprzystające, anachroniczne narracje próbuje się wprzęgnąć do wizji przyszłości, wychodząc z założenia, że „lepsze stare coś niż nowe nic, albo próbując $\mathrm{w}$ ten sposób poradzić sobie $\mathrm{z}$ ograniczeniem własnych horyzontów". Jednym zdaniem - brakuje nam nowych sposobów opowiadania o świecie ${ }^{43}$. Żyjemy w rzeczywistości wielogłosowych narracji

${ }^{40}$ J. Kozielecki, Społeczeństwo transgresyjne..., ed. cit., s. 135.

${ }^{41}$ E. Curie, Maria Curie, Warszawa 1972.

${ }^{42}$ J. Kozielecki, Transgresja i kultura, ed. cit., s. 121.

${ }^{43}$ Rozważając temat narracji, Charles Taylor odnosi się do analizy przeżyć i twierdzi, że nie ma „czystych” przeżyć, wręcz przeciwnie - są one zawsze uwikłane w jakąs interpretację. Przeżycie nie jest nigdy korelatem zespołu wszystkich fizycznych cech danego stanu rzeczy, lecz zawsze zespołem cech zrelatywizowanych do hierarchii istotności przeżywającego podmiotu (Ch. Taylor, Źródła podmiotowości. Narodziny tożsamości nowoczesnej, Warszawa 2001). 
pierwszoosobowych. Tokarczuk zakłada możliwość istnienia nowego rodzaju narratora - „czwartoosobowego”, który nie sprowadza się do „jakiegoś konstruktu gramatycznego, ale potrafi zawrzeć w sobie zarówno perspektywę każdej z postaci, jak i umiejętność wykraczania poza jej horyzont, który widzi więcej i szerzej, który jest w stanie zignorować czas". Odpowiadałoby to koncepcji Jerome’a Brunera, wedle której narracyjny sposób myślenia wyraża się opowiadaniem o zmienności ludzkich intencji na przestrzeni czasu. Dzięki niemu rozumienie świata społecznego i samego siebie w tym świecie jest uzyskiwane poprzez budowanie opowieści na temat ludzi i ich losów, przez wiązanie, układanie i wyjaśnianie zachowań z uwzględnieniem reguł świata wewnętrznego (intencji, potrzeb, uczuć, przekonań). Narracyjny sposób myślenia wyraża się najdobitniej w opowiadaniu historii. Paradygmatyczny sposób myślenia - w odróżnieniu od narracyjnego - odnosi się do rozumienia świata przez uogólnienia i detekcję powiązań między zdarzeniami, uzyskiwanymi przez logiczne uzasadnienia i poszukiwanie głównie przyczynowości fizycznej ${ }^{44}$.

Myślę - twierdzi Tokarczuk - że czeka nas przedefiniowanie tego, co rozumiemy dziś pod pojęciem realizmu, i poszukiwanie takiego, który pozwoliłby nam przekroczyć granice naszego ego, przeniknąć przez ten szybo-ekran, przez który widzimy świat. Widzieć wszystko to uznać ostateczny fakt wzajemnego powiązania rzeczy istniejących w całość, nawet jeżeli te związki nie zostały jeszcze przez nas poznane. Widzieć wszystko oznacza też zupełnie inny rodzaj odpowiedzialności za świat. Staje się oczywiste, że każdy gest „tu” jest powiązany z gestem „tam”, że decyzja podjęta w jednej części świata będzie skutkowała efektem w innej jego części, że rozróżnienie na „moje” i „twoje” zaczyna być dyskusyjne. Może powinniśmy zaufać fragmentowi, jako że fragmenty tworzą konstelacje zdolne opisać więcej i w bardziej złożony sposób, wielowymiarowo. Nasze opowieści mogłyby się w nieskończony sposób odnosić do siebie, a ich bohaterowie wchodzić ze sobą w relacje. „Dlatego wierzę, że muszę opowiadać tak, jakby świat był żywą, nieustannie stawającą się na naszych oczach jednością, a my jego - jednocześnie małą i potężną - częścią".

\section{Refleksja końcowa}

Problematyka zawarta w wygłoszonych przemowach noblistek wyznaczyła perspektywę trzech kluczowych pojęć w podjętym dyskursie. Dotyczy on w pierwszej kolejności dramaturgii w obrazie współczesności - gdzie, jak

${ }^{44}$ J. Bruner, op. cit., s. 65. 
mówi Olga Tokarczuk, „świat umiera, a my tego nie zauważamy”, Wisława Szymborska stwierdza: „życie pisze najbardziej oryginalne, najbardziej komiczne, a jednocześnie najbardziej dramatyczne scenariusze", i w którym według Marii Skłodowskiej-Curie „niczego nie należy się bać, należy to tylko zrozumieć". Wobec uciążliwości i dolegliwości współczesnego świata zarysowuje się przekonanie, iż „myśląc twórczością, świat zobaczymy inaczej”. W ukazanych narracjach kobiet mamy do czynienia z twórczością dojrzała i wybitna (elitarna). Podejmowane są w niej ważne cele i rozwiązywane problemy, które z perspektywy społecznej są uznane za twórcze oraz prowadzą do powstania dzieł zmieniających w sposób zasadniczy dziedzinę aktywności. Proces twórczy wiąże się tutaj z tworzeniem nowych wewnętrznych i zewnętrznych rzeczywistości, powstawaniem nowych wartości wyłaniających się z konfliktu „starego” z „nowym”. Obecne są tutaj dwa rodzaje twórczości. Jeden jest związany $z$ instynktem twórczym, prowadzącym do powstawania dzieł literackich i naukowych, a drugi - z samodoskonaleniem, z wielopoziomowym rozwojem osobowości odbywającym się przez wewnętrzne rozdarcia. Połączenie obu tych instynktów, niejako „wtopienie się” instynktu twórczego w instynkt doskonalenia się umożliwia autentyczny, bogaty i pełny rozwój osobowości i twórczości ${ }^{45}$. Mechanizmy motywacyjne do podejmowania aktywności twórczej wykazują orientację „na Ja” (hubrystyczna), na problem i dzieło (poznawcza/epistemiczną i kreacyjna) oraz na działanie (powinność, sprawczość $)^{46}$. Warto mieć przekonanie, iż dyskurs podjęty wokół dramaturgicznych wymiarów współczesności ukazuje pozytywną wizję człowieka jako podmiotu stającego się, zdolnego do poszerzania granic Ja oraz osobowego doświadczenia - poprzez proces tworzenia - w kierunku działań transgresyjnych ${ }^{47}$. Aktywność transgresyjna pozwala przekształcać rzeczywistość, a wykraczanie poza granice, w których działa jednostka, stanowi jakby ko-

${ }^{45}$ Tak jak w teorii dezintegracji pozytywnej Kazimierza Dąbrowskiego (K. Dąbrowski, Dezintegracja pozytywna, Warszawa 1979).

${ }^{46}$ Efekt synergii, w którym uzyskujemy zwielokrotnione korzyści dzięki umiejętnemu połączeniu części składowych całości.

${ }^{47}$ Zagadnieniu transgresyjnego ujęcia doświadczenia człowieka oraz różnorodności światów transgresji poświęcono opracowania autorskie: M. Wróblewska, Expanding the Boundaries of Self: Self - Realization, Trangression, and Creative Competence, „Rocznik Teologii Katolickiej” 2018, t. XVII/2, s. 163-174; M. Wróblewska, Człowiek - Sprawca transgresyjny. Podejście badawcze w aspekcie twórczym i biograficznym, [w:] Homo transgressivus $w$ poszukiwaniu sensu istnienia. Od transgresji do transcendencji?, red. A. Ciążela, S. Jaronowska, Warszawa 2019, s. 155-177; M. Wróblewska, Zasoby, potencjat i możliwości człowieka w perspektywie samorealizacji, „Chowanna” 2020, 5(22), s. 90-105; M. Wróblewska, Podmiotowość i Twórczość. Przestrzenie rozwoju duchowego w świetle poetyckiej myśli Karola Wojtyty, „Studia Paedagogica Ignatiana” 2021, vol. 24, nr 1, s. 101-117; M. Wróblewska, Myślenie wedtug świata wartości. Przestrzenie (w) dialogu pedagogów serca, „Biografistyka Pedagogiczna” 2021, nr 2 (w druku). 
lejne akty stwarzania lub przynajmniej p o s z e r z a n i a świata. Zdolność do wytwarzania oryginalnych interpretacji doświadczeń w toku poznawania świata i konstruowania wiedzy wpisuje się w obszar problematyki twórczości osobistej (życiowej).

\section{BIBLIOGRAFIA}

Biliński L., Z Mazowsza do sławy paryskiego Panteonu, Warszawa 2003.

Brain D., Rodzina Curie. Nigdy nie opowiedziana historia zycia prywatnego i pracy najbardziej kontrowersyjnej rodziny w dziejach nauki, Warszawa 2005.

Bruner J., O poznawaniu. Szkice na lewa ręke, przeł. E. Krasińska, Warszawa 1971.

Curie E., Maria Curie, Warszawa, 1972.

Dąbrowski K., Dezintegracja pozytywna, Warszawa 1979.

Foucault M., Przedmowa do transgresji, [w:] Osoby. Transgresje 3, red. M. Janion, S. Rosiek, Gdańsk 1984.

Fromm E., Mieć czy być, Poznań 1999.

Gadamer H.-G., Aktualność piękna. Sztuka jako gra, symbol i święto, Warszawa 1993.

Gałdowa A., Powszechność i wyjatek, Kraków 2000.

Gołaszewska M., Twórczość a osobowość twórcy. Analiza procesu twórczego, Lublin 1958.

Gołaszewska M., Gołaszewski T., Estetyka granicy, Kraków 2010.

Ingarden R., Ksiażeczka o człowieku, Kraków 1973.

Isaacson W., Steve Jobs, Warszawa 2011.

Kozielecki J., Koncepcja transgresyjna cztowieka. Analiza psychologiczna, Warszawa 1987.

Kozielecki J., Spoteczeństwo transgresyjne. Szanse i ryzyko, Warszawa 2004.

Kozielecki J., Transgresja i kultura, Warszawa 2002.

Kozielecki J., Z Bogiem albo bez Boga. Psychologia religii - nowe spojrzenie, Warszawa 1991.

Krajewska A., Dramaturgia sztuki, „Przestrzenie Teorii” 2019, 31, s. 7-12.

Maria Curie i córki. Listy, przeł. T. Pogwizd, M. Mendychowski, Wrocław 2011.

Maslow A.H., Motywacja i osobowość, Warszawa 1999.

Maslow A.H., W stronę psychologii istnienia, Warszawa-Poznań 1986.

Nęcka E., Psychologia twórczości, Gdańsk 2001.

Nycz R., Poetyka doświadczenia. Teoria - nowoczesność - literatura, Warszawa 2012.

Opoczyńska M., Wprowadzenie do psychologii egzystencjalnej, Kraków 1999.

Popek S., Barwy i psychika. Percepcja. Ekspresja. Projekcja, Lublin 2012.

Popek S., Człowiek jako jednostka twórcza, Lublin 2001.

Popek S., Do Michała Anioła, [w:] idem, Tryptyk z Michatem Aniotem, Lublin 1997.

Popek S., Nić Adriadny, [w:] idem, Srebrne ogrody, Lublin 2003.

Popek S., Psychologia twórczości plastycznej, Kraków 2010.

Simmel G., Filozofia życia: cztery rozdziały metafizyczne, Warszawa 2007.

Stróżewski W., Dialektyka twórczości, Kraków 1983.

Strzałecki S., Twórczość a style rozwiazywania problemów praktycznych. Ujęcie prakseologiczne, Wrocław 1989. 
Szymborska W., Poeta i Świat, odczyt noblowski (Sztokholm, 7 grudnia 1996), [w:] eadem, Wiersze wybrane. Wybór i uktad autorki, Kraków 2000.

Taylor Ch., Źródła podmiotowości. Narodziny tożsamości nowoczesnej, Warszawa 2001. Tokarczuk O., Czuty narrator, odczyt noblowski (Sztokholm, 10 grudnia 2019).

Wojnar I., Trzy wymiary estetycznej samowiedzy człowieka, „Sztuka i Filozofia” 1994, 8. Wróblewska M., Człowiek - Sprawca transgresyjny. Podejście badawcze w aspekcie twórczym i biograficznym, [w:] Homo transgressivus w poszukiwaniu sensu istnienia. Od transgresji do transcendencji?, red. A. Ciążela, S. Jaronowska, Warszawa 2019, s. 155-177.

Wróblewska M., Expanding the Boundaries of Self: Self - Realization, Trangression, and Creative Competence, „Rocznik Teologii Katolickiej” 2018, t. XVII/2, s. 163-174.

Wróblewska M., Kompetencje twórcze w dorosłości, Białystok 2015.

Wróblewska M., Myślenie wedtug świata wartości. Przestrzenie (w) dialogu pedagogów serca, „Biografistyka Pedagogiczna” 2021, nr 2 (w druku).

Wróblewska M., Podmiotowość $i$ Twórczość. Przestrzenie rozwoju duchowego w świetle poetyckiej myśli Karola Wojtyty, „Studia Paedagogica Ignatiana” 2021, vol. 24, 1, s. $101-117$.

Wróblewska M., Zasoby, potencjał i możliwości człowieka w perspektywie samorealizacji, „Chowanna” 2020, 2/5(22), s. 90-105.

Halina Monika Wróblewska - dr hab., prof. UwB, Wydział Nauk o Edukacji, Katedra Studiów Społecznych i Edukacyjnych. Główne wątki działalności naukowo-badawczej: 1. podmiotowe kompetencje twórcze i uwarunkowania ich rozwoju; 2. doświadczenia twórcze w narracjach i materiałach biograficznych; 3. diagnozowanie, kształcenie i wspomaganie rozwoju zdolności i uzdolnień twórczych; 4. sztuka i twórcza ekspresja w rozwijaniu i wspomaganiu twórczego samorozwoju. Autorka pięciu monografii i prac pod redakcją oraz kilkudziesięciu artykułów w obszarze przedstawionej problematyki. Obecnie pracuje nad zagadnieniem transgresyjnej istoty kreacji w perspektywie biograficznej. ORCID: 0000-0002-1985-3877. Adres e-mail: <h.wroblewska@uwb.edu.pl>.

Halina Monika Wróblewska - PhD (dr hab.), professor of the University of Białystok, Faculty of Education, Department of Social and Educational Studies. The main strands of her scientific and research activity are: 1 . Subjective creative competences and conditions for their development; 2. Creative experiences in narratives and biographical materials. 3. Diagnosing, educating and supporting the development of creative abilities and talents. 4. Art and creative expression in developing and supporting creative self-development. Author of five monographs and edited works, and several dozen articles in the area of the above issues. Currently working on the issue of the transgressive essence of creation from a biographical perspective. ORCID: 0000-00021985-3877. E-mail address: <h.wroblewska@uwb.edu.pl>. 